\title{
18
}

\section{Environmental Psychology}

\author{
Robert Gifford, Linda Steg, and Joseph P. Reser
}

Environmental psychology is the study of transactions between individuals and their physical settings (Gifford, 2007a). In these transactions, individuals change their environments, and their behavior and experiences are changed by their environments. It includes theory, research, and practice aimed at making the built environment more humane and improving human relations with the natural environment. Considering the enormous investment society makes in the physical environment (including buildings, parks, streets, the atmosphere, and water) and the huge cost of misusing nature and natural resources, environmental psychology is a key component of both human and environmental welfare.

Environmental psychologists work at three levels of analysis: (a) fundamental psychological processes like perception of the environment, spatial cognition, and personality as they filter and structure human experience and behavior, (b) the management of social space: personal space, territoriality, crowding, and privacy, and the physical setting aspects of complex everyday behaviors, such as working, learning, living in a residence and community, and (c) human interactions with nature and the role of psychology in climate change (e.g., Gifford, 2008a).

The history of environmental psychology has been reviewed elsewhere (see Bechtel \& Churchman, 2002, Bell, Greene, Fisher, \& Baum, 2001, and Gifford, 2007a). But, for perspective, we note that early 20th century psychologists studied the effect of noise (United States) and heat (England) on work performance, while scholars in Germany and Japan explored concepts and moral philosophy related to environmental psychology. By mid-century, environmental psychology was a clearly established discipline with work on topics such as sensory isolation, personal space, and building design. Journals devoted to the field were established; the most prominent of these are the Journal of Environmental Psychology and Environment and Behavior.

The IAAP Handbook of Applied Psychology, First Edition. Edited by Paul R. Martin, Fanny M. Cheung, Michael C. Knowles, Michael Kyrios, Lyn Littlefield, J. Bruce Overmier, and José M. Prieto.

(C) 2011 Blackwell Publishing Ltd. Published 2011 by Blackwell Publishing Ltd. 
While recognizing the value of theory and research, many environmental psychologists nevertheless prefer to apply knowledge. Instead of working in an research setting, many enter into consultancy or public service to make good use of research findings for developing policy or solving local problems. Some are geared to improving the built environment (e.g., Preiser, Vischer, \& White, 1991), while others are dedicated to overcoming sustainability problems in the natural and global ecosystems (e.g., Gifford, 2007b; Nickerson, 2003).

\section{The Distinctiveness of Environmental Psychology}

Most psychologists examine the relations between environmental stimuli and human responses in one way or another. However, what sets environmental psychology apart is its commitment to research and practice that subscribe to these goals and principles: (a) Improve the built environment and stewardship of natural resources, (b) Study everyday settings (or close simulations of them), (c) Consider person and setting as a holistic entity, (d) Recognize that individuals actively cope with and shape environments; they do not passively respond to environmental forces, (e) Work in conjunction with other disciplines. Figure 18.1 broadly depicts the scope of environmental psychology.

\section{Theoretical Bases}

Seven major theoretical approaches guide environmental psychologists, although many focused theories deal with specific issues. First, stimulation theories conceptualize the physical environment as a crucial source of sensory information (e.g., Wohlwill, 1966). The adaptation-level approach begins with the assumption that people adapt

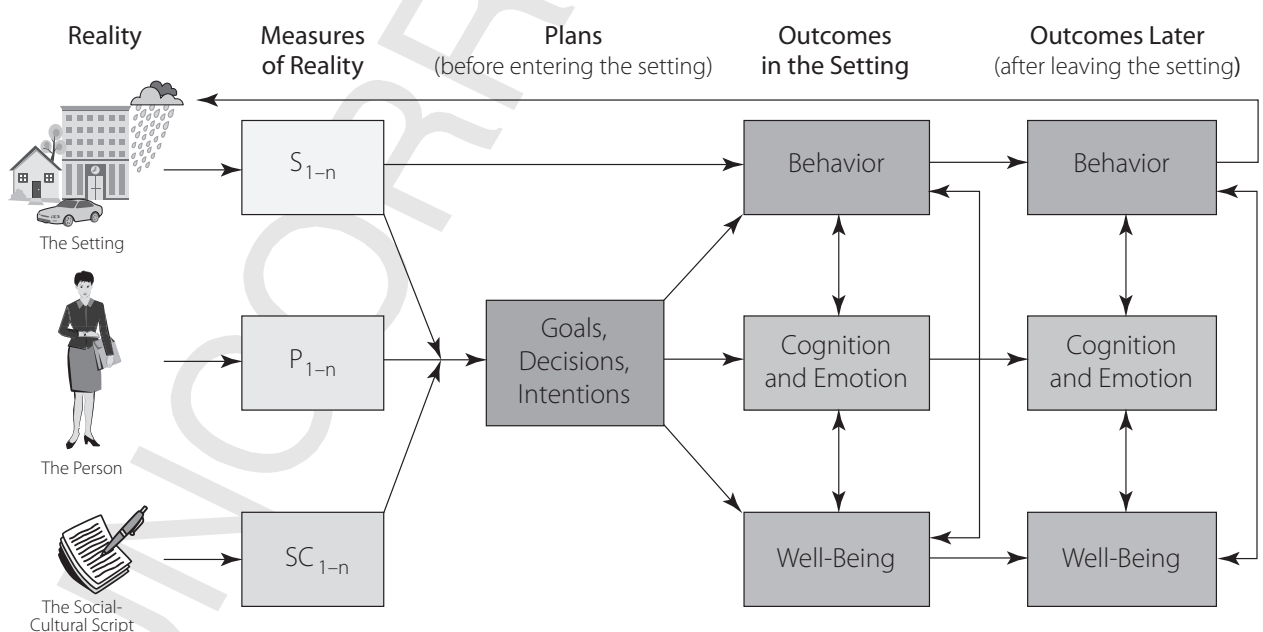

Figure 18.1. An overview of environmental psychology's scope (Gifford, 2007a) 
to a certain level of environmental stimulation (e.g., Helson, 1964). Too much or too little stimulation is the focus of arousal, overload (e.g., Cohen, 1978), restricted environmental stimulation (Suedfeld, 1980), and stress theories (e.g., Evans, 1982). Second, control theories emphasize the importance of an individual's real, perceived, or desired control over stimulation (e.g., Barnes, 1981), and boundary regulation theories (e.g., Altman, 1975). Third, ecological psychology asserts the importance of behavior settings, naturally occurring small-scale social-physical units consisting of regular patterns of person-environment behavior (Barker, 1968). Fourth, integral approaches such as interactionism, transactionalism, and organismic theory attempt to describe the full, complex interrelationship of persons and setting (Stokols \& Shumaker, 1981; Altman \& Rogoff, 1987). Fifth, operant approaches downplay abstract principles, instead adopting a direct problem-solving approach that employs behavior modification techniques (e.g., Geller, 1987). Sixth, environment-centered theories such as the spiritual-instrumental model and ecopsychology raise the issue of the environment's own welfare and its ability to support our own well-being (e.g., Clayton \& Brook, 2005). Seventh, social psychology-based theories explain which factors affect proenvironmental behaviour and how they can be encouraged.

\section{Environmental Perception and Spatial Cognition}

Environmental psychologists emphasize understanding how individuals respond to complex everyday scenes (e.g., Ittelson, 1978). A person's level of awareness, degree of adaptation, and necessary selectiveness in attending to environmental cues within complex real scenes mean that people sometimes miss important elements of a scene resulting in negative consequences for health or safety (e.g., Stamps, 2005). Environmental perception varies importantly with personal and cultural differences; people often see and interpret the same scene differently. Brunswik's (1956) probabilistic functionalism (see Figure 18.2.), Gibson's (1976) theory of affordances, Berlyne's

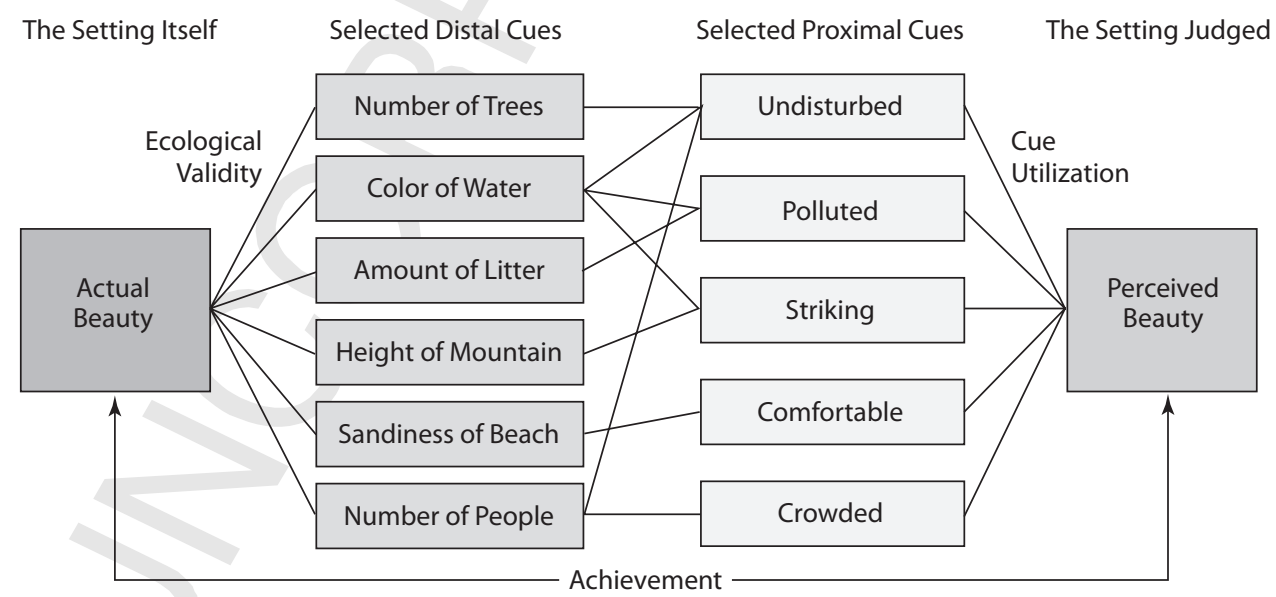

Figure 18.2. Brunswik's lens model, adapted for environmental perception (Gifford, 2007a) 
(1974) collative properties, and the phenomenologist's approach (e.g., Seamon, 1982 ) all represent valuable ways to understand how people "read" their world.

Spatial cognition researchers have shown that human information processing does not resemble mechanical information processing (e.g., Lynch \& Rivkin, 1959), yet is generally effective. However, spatial cognition heuristics that ordinarily work sometimes lead to errors (e.g., Montello, 1991). Theories of spatial cognition begin from different points of departure: the setting itself (e.g., Lynch, 1960), cognitive development (e.g., Moore, 1979), and brain physiology (e.g., O'Keefe \& Nadel, 1978). Some of the most useful practical research has resulted in better signs for wayfinding in buildings and transit (Levine, 1982), and for helping people afflicted with Alzheimer's to navigate more easily (Passini, Pigot, Rainville, \& Tetreault, 2000).

\section{Managing Social Space}

People use the physical space among them according to complex rules and strong preferences. Although these rules and preferences are not always conscious, their importance suddenly becomes clear when they are compromised. Personal space, territoriality, and crowding are the main dimensions of social space.

\section{Personal space}

Personal space is the dynamic distance and orientation component of interpersonal relations (Gifford, 2007a). It has been studied longer and more than almost any other aspect of environmental psychology (e.g., Sommer, 1959).

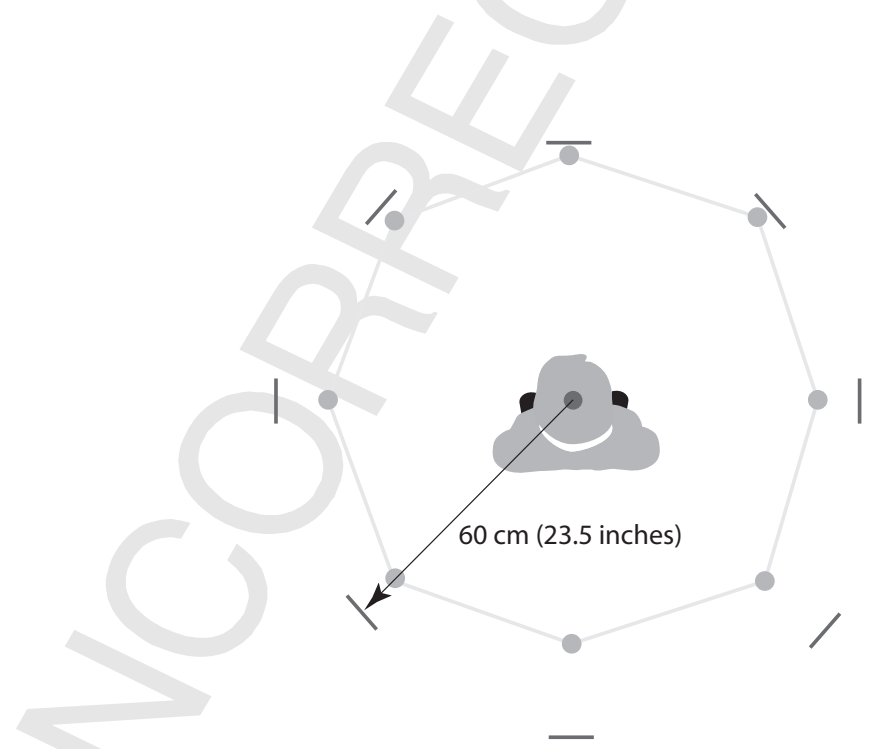

Figure 18.3. The average dimensions of personal space for North American university students approached from different directions; these distances will vary with culture and situation (from Gifford, 2007a) 
Inferences about others are often drawn on the basis of the interpersonal distance they choose (e.g., Patterson \& Sechrest, 1970). Many personal and situational influences interact with preferences for particular interpersonal distances. For example, males have larger personal spaces. Attraction and cooperation generally lead to smaller interpersonal distance, whereas less positive contexts such as stigma and unequal status lead to larger distances. When the physical setting is less spacious, larger interpersonal distances are selected. Cultural differences in interpersonal distance exist (e.g., Hall, 1966), but other factors often alter cultural preferences.

\section{Territoriality}

Territoriality in humans is a pattern of behavior and experience related to the control, usually by nonviolent means such as occupation, law, custom, and personalization, of physical space, objects, and ideas. Seven forms of territory (primary, secondary, public, objects, ideas, interactional, and body) have been distinguished (Altman, 1975); defense strategies (prevention, reaction, and social boundaries) are employed in response to infringements (invasion, violation, and contamination). Males are often more territorial than females. Careful arrangements of dwelling exteriors and street plans (defensible space) enhances residents' territoriality and reduces crime (e.g., Newman, 1972).

Personalization, marking, and status are used much more often than physical aggression to control space and ideas. Theories of territoriality stress its organizing function and evolution more than its relation to aggression (Edney, 1976). Architects can and should incorporate knowledge about territoriality to allow building users as much control as they are capable of responsibly exercising and as the organizational context allows; territory holders then benefit from a greater sense of self-determination, identity, and even safety.

\section{Crowding and density}

Crowding is a subjective experience that is only mildly related to the objective index, population density (Stokols, 1972), as is obvious to anyone at a good party or anyone who has felt crowded in another contexts by one other person. It exists in three modes (Montano \& Adamopoulos, 1984): situational (such as feeling constrained or having expectations dashed), emotional (usually negative, but positive emotions can occur), and behavioral (such as activity completion or assertiveness). Crowding is accentuated or ameliorated by personal factors (e.g., personality, expectations, attitudes, gender), social factors (e.g., the number, type, and actions of others, and attitude similarity), and physical factors (e.g., architectural features and spatial arrangements).

Prolonged high indoor population density often impairs mental and physical health, task performance, child development, and social interaction (e.g., Evans \& Saegert, 2000). Individuals in some cultures seem to cope with high density better, but sensory overload and lack of personal control lead to many negative outcomes. Short-term high density may have positive outcomes when social and physical conditions are positive. High outdoor density, as in large cities, certainly can provide an 
enjoyable variety of social and cultural experiences. In general, high density tends to magnify pre-existing social conditions (Freedman, 1975). To reduce the negative effects of high density through environmental design, more space is not always needed. Rather, careful environmental design (such as partitioning and behavioral zoning) can ease crowding within a limited space.

\section{Encouraging Proenvironmental Behavior}

Many environmental problems are rooted in human behavior, and can thus be managed by promoting proenvironmental behavior (Gardner \& Stern, 2002). Attempts to improve environmental quality via behavior changes will be more effective when one (1) selects behavior that significantly affects environmental quality, (2) examines which factors cause those behaviors, (3) applies and evaluates interventions that change these antecedents and the behavior (Geller, 2002; Steg \& Vlek, 2009). This section provides a brief overview of how environmental psychologists have addressed the last two issues.

\section{Factors that influence behaviors with environmental impact}

In order to decide which factors should be targeted to encourage proenvironmental actions, one needs to understand which factors promote or inhibit proenvironmental behavior. Below, we discuss two types of individual motivations to engage in environmental behavior: perceived cost and benefits, and normative concerns. We indicate how these perspectives may be integrated into a coherent framework. Next, we elaborate on contextual factors and habits.

\section{Motivational factors: Cost-benefit deliberations,} and normative concerns

The theory of planned behavior (TPB; Ajzen, 1991) assumes that individuals choose alternatives with highest benefits against lowest costs (e.g., in terms of money, effort, and/or social approval). The TPB proposes that behavior follows from an individual's intention. Intentions depend on attitudes towards the behavior (the degree to which engagement in behavior is positively valued), social norms (social pressure from important others to engage in a particular behavior), and perceived behavioral control (beliefs on whether one is capable of performing the behavior). The TPB was successful in explaining various types of environmental behavior, including travel mode choice, household recycling, waste composting, water use, meat consumption, and general proenvironmental behavior (e.g., Harland, Staats, \& Wilke, 1999; Heath \& Gifford, 2002).

Acting proenvironmentally is often associated with higher costs. Therefore, moral and normative concerns are believed to play an important role in environmental behavior. Indeed, people are more likely to engage in proenvironmental actions when they subscribe to values beyond their immediate own interests, that is, selftranscendent, altruistic, or biospheric values, while egoistic or self-enhancement 
values are negatively related to environmental behavior (e.g., De Groot \& Steg, 2007; 2008). Also, stronger environmental concern is associated with acting more proenvironmentally, although relationships are generally weak. Environmental concern is less predictive of behavior-specific beliefs than are values, probably because values reflect a wider range of motivations (Steg, De Groot, Dreijerink, Abrahamse, \& Siero, in press).

The norm-activation model (NAM; Schwartz, 1977) and the value-belief-norm theory (VBN theory; Stern, 2000) assume that people act proenvironmentally when they feel a moral obligation to do so, which depends on the extent to which people are aware of the problems caused by their behavior, and feel responsible for these problems and their solution. VBN theory further proposes that problem awareness is rooted in environmental concern and values. The NAM and VBN theories are reasonably successful in explaining low-cost environmental behavior and "good intentions" such as willingness to change behavior, political behavior, environmental citizenship, or policy acceptability (e.g., Gärling, Fujii, Gärling, \& Jakobsson, 2003; Nordlund \& Garvill, 2003; Steg, Dreijerink, \& Abrahamse, 2005). However, in situations characterized by high behavioral costs or strong constraints on behavior, such as reducing car use, their explanatory power is generally low (e.g., Bamberg \& Schmidt, 2003). In such settings, the TPB appears to be more powerful in explaining behavior, probably because the TPB also considers non-environmental motivations and perceived behavioral control (see Steg \& Vlek, 2009).

Cialdini, Kallgren, and Reno (1991) distinguish two types of social norms: injunctive norms (the extent to which behavior is supposed to be commonly approved or disapproved) and descriptive norms (the extent to which behavior is perceived as common practice). The most salient norm influences behavior most. Indeed, people are more likely to violate a particular norm when others do so as well (Cialdini et al., 1991). Moreover, norm violations spread, that is, when people see that a particular norm is being violated, they are more likely to violate other norms as well, suggesting that perceptions of norm violations reduce the likelihood of normative behavior in general (Keizer, Lindenberg, \& Steg, 2008).

Various scholars have integrated concepts and variables from different theoretical frameworks, showing that behavior results from multiple motivations. Goal-framing theory (Lindenberg \& Steg, 2007) explicitly acknowledges that behavior results from multiple motivations. This theory distinguishes three goals that "frame" the way people process information and act upon it: a hedonic goal-frame "to feel better right now," a gain goal-frame "to guard and improve one's resources," and a normative goal-frame "to act appropriately." In a given situation, one of these goals is presumed to be focal (it is the goal-frame), while other goals are in the background and increase or decrease the strength of the focal goal.

\section{Contextual factors}

Many contextual factors may facilitate or constrain environmental behavior and influence individual motivations, such as the availability of recycling facilities, or the quality of public transport (e.g., Ölander \& Thøgersen, 1995). Only a few scholars in this field have included contextual factors in their studies (e.g., Guagnano, Stern \& Dietz, 
1995; Stern, \& Elworth, 1985), and surprisingly, contextual factors are not typically included in theories to explain environmental behavior. When environmental psychology aims to study transactions between humans and their environments, effects of contextual factors on behavior should be studied more extensively. This may reveal whether important barriers for proenvironmental action should be removed.

\section{Habit}

The theoretical frameworks discussed above generally imply that individuals make reasoned choices. However, in many cases, environmental behavior (e.g., car use) is habitual and guided by automated cognitive processes (e.g., Aarts, Verplanken, \& Van Knippenberg, 1998). Temporarily forcing car drivers to use alternative travel modes appeared to induce long-term reductions in car use, especially among habitual car drivers (Fujii \& Gärling, 2003). This suggests that habitual drivers have inaccurate and modifiable perceptions of the pros and cons of different transport modes.

Interventions Various strategies for behavior change have been identified, each focusing on a different set of behavioral determinants. A distinction can be made between informational strategies that aim to change prevalent motivations, perceptions, cognitions and norms, and structural strategies that aim to change the context in which behavioral choices are made (Messick \& Brewer, 1983). Informational and structural strategies are described next, but their effectiveness in promoting different types of environmental behavior in detail is not, because this has been extensively reviewed elsewhere (e.g., Abrahamse, Steg, Vlek, \& Rothengatter, 2005; Dwyer, Leeming, Cobern, Porter \& Jackson, 1993).

\section{Informational strategies}

Informational strategies target motivational factors, without actually changing the external context in which choices are made. First, informational strategies can be aimed to increase actors' awareness of environmental problems and of the environmental impacts of their behavior, and/or to increase their knowledge of behavioral alternatives and their pros and cons. Information campaigns hardly result in behavior changes (see Abrahamse et al., 2005, for a review).

Second, persuasion strategies may be employed, for example, to influence actors' attitudes, strengthen their altruistic and ecological values, and/or strengthen their commitment to act proenvironmentally. Commitment strategies appeared to be successful in encouraging proenvironmental behavior (see Abrahamse et al., 2005). Eliciting implementation intentions in which people not only indicate that they intend to change their behaviour, but also how they plan to do so, appeared to be effective as well (e.g., Bamberg, 2002). Furthermore, promising results have been found with individualized social marketing approaches, in which information is tailored to the needs, wants and perceived barriers of individual segments of the population (e.g., Abrahamse et al., 2007).

Third, social support and role models can be provided to strengthen social norms, and to inform individuals about the perceptions, efficacy, and behavior of others. 
Modeling and providing information about the behavior of others appeared to be successful in supporting proenvironmental behavior. However, comparative feedback can be counterproductive when people take the behavior of others as a reference point for which to strive. This boomerang effect can be neutralized by adding injunctive norm information, which conveys social approval (Schultz, Nolan, Cialdini, Goldstein, \& Griskevicius, 2007).

Informational strategies in themselves are especially effective when the proenvironmental behavior is not very costly, and when individuals do not face severe external constraints on behavior. Furthermore, they are an important element in the implementation of structural strategies that force individuals to change their behavior.

\section{Structural strategies}

When acting proenvironmentally is rather costly or difficult because of external barriers to proenvironmental actions, the circumstances under which behavioral choices are made need to be changed as to make proenvironmental actions more attractive, and to reduce the attractiveness of environmental harmful actions. First, the availability and quality of products and services may be altered via changes in physical, technical, and/or organizational systems (e.g., provision of recycling bins). Second, legal regulations can be implemented (e.g., prohibiting the use of harmful propellants in spray cans). Third, prices of different behavior options may be changed (e.g., road pricing, CO2 taxes).

Structural strategies either aim to reward approved behavior, or punish disapproved behavior. When rewards and penalties are strong, people can attribute their behavior change to the incentive and not to their personal convictions. As a result, attitudes may not change and behavior changes will only last for as long as the incentive is in place. Rewards will be not be effective if they fail to make proenvironmental behavior more attractive than environmentally harmful options, to activate goals to change behavior, and to facilitate the implementation of such goals (Gärling \& Schuitema, 2007).

Evaluating the effectiveness of interventions Studies aimed at evaluating an intervention's effectiveness should follow experimental research designs that reveal the effectiveness of single as well as combinations of interventions for one or more "treatment" groups and a comparable control group. Because an intervention may have only short-lived effects, whether it has lasting long-term effects needs study (Abrahamse et al., 2005). First, it is important to monitor (changes in) behavioral determinants in order to understand why intervention programs were successful or not. Moreover, it allows change agents to adapt interventions to increase its effectiveness. Second, changes in environmental impact should be monitored, because this is the ultimate goal of behavioral interventions in the environmental domain. Based on this, feedback can be provided to the target population so as to inform members about the effects of their efforts on environmental quality. This may strengthen their commitment to change behavior, and to maintain the changes realized. Third, one also would need to know about changes in people's quality of life, which is an important component of the more general notion of sustainable development (Steg \& Gifford, 2005). 
Besides studying the actual effects of interventions, environmental psychologists have studied the perceived effectiveness and acceptability of environmental policies before such policies are implemented, particularly in the travel domain (see Steg \& Schuitema, 2007, for a review). These studies reveal, among other things, that policies are more acceptable when they are believed to be more fair, when they are effective in reducing relevant problems, and when they do not seriously affect individual freedom. Moreover, policies are more acceptable to people who have strong environmental values, who are highly aware of the problem, and who feel a strong moral obligation to reduce the problems. Policies that increase the attractiveness of proenvironmental behavior are evaluated as more effective and acceptable than policies aimed at decreasing the attractiveness of environmentally harmful behavior, and people prefer policies aimed at promoting the adoption of energy-efficient equipment to policies aimed at reducing the use of existing equipment (e.g., Poortinga, Steg, Vlek \& Wiersma, 2003; Steg, Dreijerink \& Abrahamse, 2006).

Conclusions Environmental psychologists have an important role to play in the management of environmental problems through the promotion of behavior change. Behavioral interventions are generally more effective when they are systematically planned, implemented, and evaluated. Individuals can contribute significantly to achieving long-term environmental sustainability by adopting proenvironmental behavior patterns. The challenge for environmental psychologists is to understand the individual and structural factors and processes that threaten environmental sustainability, so that proenvironmental behaviors can be facilitated worldwide.

\section{The Psychology of Resource Management}

Energy conservation, recycling, fresh water, and pollution are instances of everyday commons dilemmas. The choices people make-sometimes to take (as in fishing) and sometimes to give (as in greenhouse gases) influence the fate of many desirable resources. People in commons dilemmas must decide whether to try to serve their own interest quickly, which risks total failure for self, others, and the resource, or, through restraint, to benefit all participants more moderately, with the crucial consequence that the resource is preserved for the future (Hardin, 1968). Many characteristics of the resource, individuals, and proximate constraints that influence these choices have been identified (see Figure 18.4).

For example, conservation often (but not always) improves when the resource becomes scarce. Uncertainty about the resource almost always leads to overharvesting. Narcissistic or egocentric harvesters take more than others (e. g., Biel \& Garling, 1995). When more harvesters have access to a resource, each tends to take more, but if they have a sense of community, cooperation is greater (e.g., Dawes \& Messick, 2000). Regulations do not govern harvesting absolutely, but of course they have an influence. For example, when harvests are publicly known, cooperation is greater and when the resources are partitioned into zones that each harvester controls, the commons is managed more sustainably. 


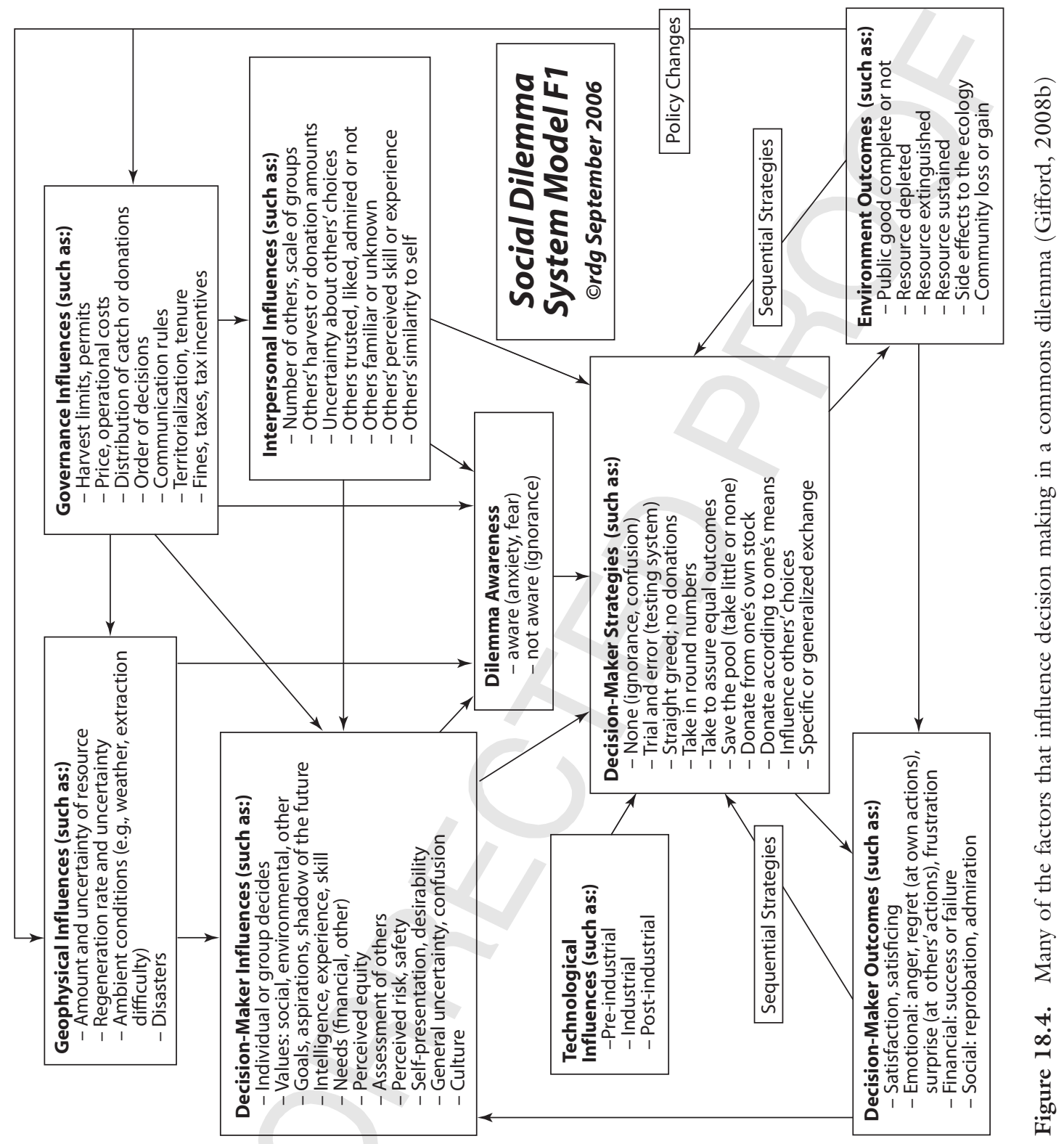




\section{Residential Environmental Psychology}

Home is the most important physical setting for most people. Environmental psychologists distinguish the physical structure (house, apartment) from its meaning structure (home). Individuals normally called homeless might more properly be called houseless, although if their last residence loses its meaning, they truly are homeless. Residential satisfaction depends on many determinants, including stage of life, socioeconomic status, personality and values, hopes for the future, norms for one's peers, and relationships with neighbors. Of course, physical features of the residence-such as its form (Michelson, 1977), architectural style (Nasar, 1989), floor plan, colors, outdoor areas around the residence, as well as cultural background affect residential preferences, choices, and satisfaction. Poor-quality housing affects the socioemotional health of children and adults (Evans, Wells, Chan, \& Saltzman, 2000; Gifford, 2007c; Gifford \& Lacombe, 2006).

People arrange their residential interiors in fairly predictable patterns that are related to lifestyle, social class, and culture (e.g., Bonnes, Giuliani, Amoni, \& Bernard, 1987). Adapting to new residences can be stressful, depending on whether a person has some choice in doing so, prefers to explore new settings in general (Stokols \& Shumaker, 1982), or represents a downgrading.

In relation to the amount of time people spend in their residences, and their psychological importance, this aspect of environmental psychology is under-researched. This is partly because conducting research in residences usually is, understandably, seen as an intrusion of privacy.

\section{The Environmental Psychology of Neighborhoods and Cities}

A vast global movement to the city is underway. What happens once nearly everyone lives so close together? Environmental psychologists explore person-environment relations in cities, public places, the neighborhood, the community, and on the streets. A general model for this is presented in Figure 18.5.

Residents' personal factors and the physical aspects of the city (stressors and amenities) are presumed to influence the way residents think about their cities and neighborhoods (whether they are satisfied or not, fearful or not, attached to them or not, mentally healthy or mentally unhealthy). The physical aspects of the city, personal factors, and these cognitions are presumed to affect residents' actual behavior in urban public places such as streets, parks, and stores. These behaviors may be pro-social, anti-social, or neither; they include everyday behaviors, such as how fast people walk, kids playing in parks, or where people choose to sit in public areas. They also include behavior in retail settings such as shoppers' reactions to store music and displays. The model further states that these behaviors, in turn, are presumed to influence cognitions (just as cognitions influence behaviors) and the urban planning and design process. The design process, to complete the cycle, influences the physical shape of the city as zoning and other bylaws govern what sort of buildings, streets, and parks 


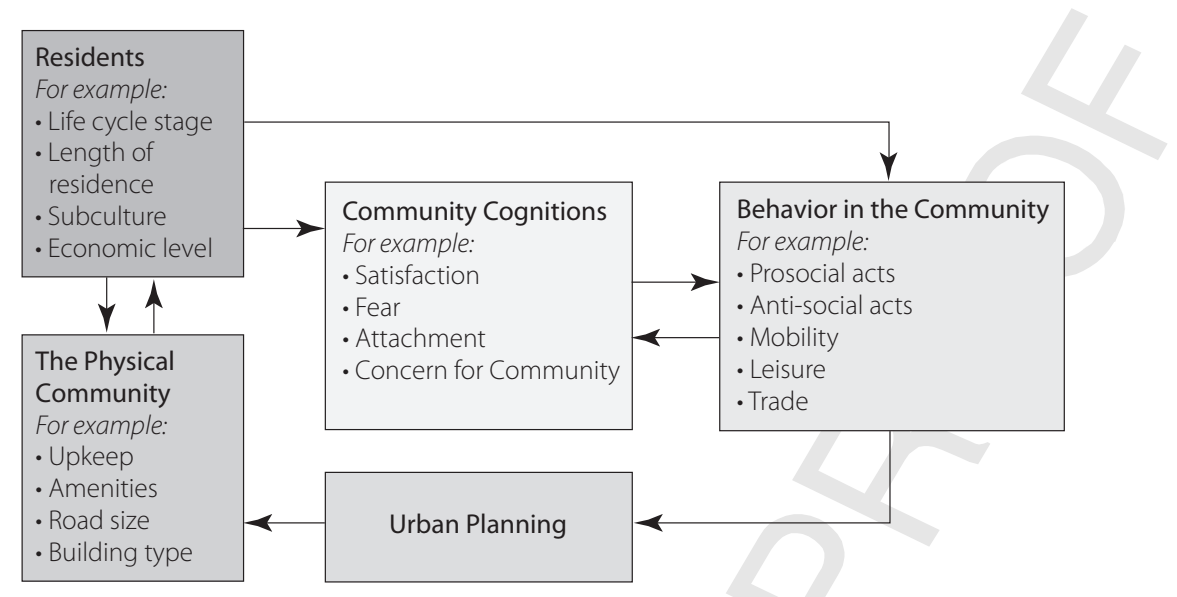

Figure 18.5. The environmental psychology of public life (Gifford, 2007a)

get built. The cycle then continues. Environmental psychologists have studied all phases of the model in Figure 18.5.

Cities can be very stressful: noise, traffic, density, and pollution usually are much greater than in rural places. We humans have only lived in such large agglomerations for a tiny fraction of the time we have been a species; it is reasonable to say that cities are unnatural. Personal safety is a very important urban problem. Some danger is caused by poverty and social breakdown, but defensible space principles combined with a take-back-the-streets community attitude can significantly reduce crime. Other physical forces facilitate urban aggressiveness: temperatures up to $85^{\circ} \mathrm{F} / 29^{\circ} \mathrm{C}$ degrees appear to increase the risk of violence (Baron \& Ransberger, 1978). A less obvious aggression-causing problem may be air pollution; in addition to being a health risk, it may also trigger violence in some individuals (Rotton, Frey, Barry, Milligan, \& Fitzpatrick, 1979).

On the other hand, cities obviously are attractive. William Whyte, a champion of the city's possibilities, argued that people gravitate toward high density and thrive on it. According to Whyte, the vendors, performers, and eccentrics make cities exciting. Clearly, cities have benefits; besides the interesting street life, these include more cultural, educational, medical, leisure, social, and shopping resources, not to mention greater opportunity for jobs. Environmental psychology has contributed scientific evidence on both the psychological benefits and costs of urban living.

Neighborhoods and retail stores: The building blocks of cities

Neighborhoods are psychological (Guest \& Lee, 1984). Generally, a neighborhood's physical qualities are more important than its social qualities (Fried, 1984), unless (on the positive side) residents have special bonds with each other or (on the negative side) residents are at war, or nearly so. However, a pleasant, green, natural, residential-only area is not everyone's favorite place; more important is whether the community fills one's needs and whether one is adapted to its pattern of stimulation (Michelson, 1977). 
Place attachment is psychologically important. It cannot be instantly attained; residents need to spend time in a place, to hear stories, to be part of a spiritual quest centered there (Hay, 1998). Many people eventually lose the places to which they have become attached, with the attendant experiences of loss and grief (Norris-Baker \& Scheidt, 1990).

People do much on local and urban streets that seems close to nothing, perhaps because they do most of it automatically, without reflecting. However, upon closer examination, this "nothing" turns out to be a fascinating mixture of thoughts and activities. We monitor our progress through the city in responsive, operational, or inferential modes (Appleyard, 1976). We walk at a speed that reflects the pulse (or at least the size) of the city (Gifford, Ward, \& Dahm, 1977). Our walks follow planned patterns even when we are unaware of our plans. We carefully avoid interaction with most people we meet on the street, but we try to maximize social order (Lofland, 1973). Surprisingly, perhaps, elderly men hang out in malls more than teens (Brown, Sijpkes, \& MacLean, 1986). We "know" some people in public places that we do not really know-familiar strangers (Milgram, 1977).

The physical environment is not widely studied as a factor in retail behavior, but awareness of and research on its influence is growing (e.g., $\mathrm{Ng}, 2003$ ). Well-known effects include location and store size. However, at the interior level, the way that shelves, aisles, displays, and odors affect the emotions and behavior of consumers is gradually becoming clear (Hawkins, Best, \& Coney, 1983).

\section{Educational Environmental Psychology}

The physical features of schools and other learning settings as a whole affect student and teacher outcomes. For example, many learning experiences are affected by school size (e.g., Barker \& Gump, 1964). Students in larger schools have an edge in the variety of things they can learn about. Yet, partly because time at school is limited, students in large schools do not actually participate in more activities than students in small schools. Students in large schools more often learn and enjoy as spectators; students in small schools more often learn and enjoy as participants. In most areas of learning, students in small schools achieve more because they develop competence through direct involvement in activities.

Interior school design has a variety of influences on students and teachers (e.g., Ahrentzen, 1981). Temporary or low walls increase distractibility. Acquisition, maintenance, and dynamic walls can be strategically used to match students' normal viewing patterns with current versus background educational information (Creekmore, 1987). When students learn in a given setting, that material is better recalled in the same setting - or when a vivid memory of that setting is evoked (e.g., Smith, 1979).

Evidence strongly suggests that noise interferes with learning both while it occurs and, if the learner is subjected to noise for long periods, even after the noise is gone (Cohen \& Weinstein, 1982). To combat noise, instructors have changed their methods-sometimes sacrificing a good pedagogical technique for a quiet one-and successfully employed behavior modification techniques such as sound-activated 
electrical relays that control reinforcers such as music and extra recess time (e.g., Strang \& George, 1975).

Incandescent lighting is preferred by many, but it is more expensive than fluorescent lighting, which has not been shown to have dramatic negative effects on the performance or health of most students. Despite the inadequate methodology in some studies, and the lack of significant differences in others, it appears that light does affect some kinds of performance, such as basic cognitive and motor activities (Munson \& Ferguson, 1985). Short exposures to the different kinds of light in many studies may have led to incorrect conclusions that light has no effects. As with noise, the important effects may be on specific subgroups of individuals; when studies of whole classes or schools are done, large effects on a few learners may be obscured by the absence of effects on most learners.

Few simple, direct relations exist between indoor climate and educational behavior. Perhaps the best-supported conclusion is that performance is best in slightly cool but not humid classrooms (Ahrentzen, Jue, Skorpanich, \& Evans, 1982).

The amount, arrangement, and design of space in educational settings is very important for classroom performance and related behaviors. High density may affect learning when the activity involves physical movement around the classroom, when learning depends on some classroom resource that is not increasing as fast as the number of learners, when a particular situation seems crowded to a learner, and when the concept to be learned is complex (e.g., Rohe \& Patterson, 1974). Among preschoolers, high density alters the child's choice of activities and time spent on off-task activities (e. g., Kantrowitz \& Evans, 2004). Numerous classroom arrangement features have been linked to educational performance (e.g., Weinstein, 1977; Koneya, 1976). All such findings depend in part on grade level, type of tasks, and teaching style.

High density may affect learning (e. g., Weinstein, 1979). Space in classrooms affects student and teacher feelings. Most students and teachers prefer lower-density classrooms, because lower densities usually feel less crowded. Providing satisfying physical arrangements within schools is best accomplished by furnishing a variety of layouts. Softer, more home-like classrooms appear to improve student learning (e.g., Wollin \& Montagne, 1981), but will not become common until the attitudes of authorities, teachers, and students change. In terms of social behavior, increased social density leads to increased aggression and withdrawal when other resources, architectural features, and teaching style do not counteract it (Weinstein, 1979).

Environmental competence involves learning about the environment (Steele, 1980). Three kinds of it include (1) personal style, attitudes and awareness of physical setting; (2) knowledge of physical settings, including technical knowledge, how to unearth new information, knowledge about how social systems control space, knowledge of person-environment relations; and (3) practical environmental skills such as scouting, matching, personalization, and creative custodianship. Programs in and out of school teach many different facets of environmental competence, from basic environmental ethics to campfire starting to architectural design. Although some subareas of environmental competence have received attention, the concept as a whole so far has not received as much as the concept deserves. 


\section{Workplace Environmental Psychology}

Working can provide some of the best and some of the worst experiences in life. Many factors determine a person's productivity, stress, and satisfaction at work but, for decades, psychologists have realized that the physical environment is an important influence on employee productivity and satisfaction.

Environmental psychologists conduct research on the relations between the physical environment and (a) getting to work, (b) performance, feelings, social behavior, health, and stress at work, and (c) trying to enjoy life after work (by traveling). Throughout, the tempting but simplistic notion that changes in the physical setting will directly determine employee behavior must be rejected.

\section{Getting to work}

Most research on getting to work has been broadly concerned with encouraging people to choose less energy-intensive means of commuting as part of the general drive towards sustainability. Environmental psychologists have created demographic profiles of car and urban transit riders (e.g., Hartgen, 1974), devised models of commuter preference (Levin \& Louviere, 1981), provided positive information about urban transit and evaluated existing transit systems (E. Stern, 1982), offered reduced fares (Studenmund \& Connor, 1982), and promoted car sharing (Bonsall, Spencer, \& Tang, 1983). Commuting often is stressful, but the majority still drive, suggesting that the description of it as an addiction (Reser, 1980) is not far wrong. However, the more promising approaches are being sorted out from the less promising ones, and progress must be made, because the worldwide growth in cars and driving is not sustainable, and certainly has very mixed effects on the quality of life (e.g., Gifford \& Steg, 2007).

\section{At work}

Noise has many effects on work activities and feelings. In industrial settings, it can cause serious hearing loss. Loud noise is particularly dangerous when employees do not realize that deafness comes slowly and almost imperceptibly. Despite the common supposition that noise affects performance, research in natural settings shows (a) how complex the issue is and (b) that performance decrements depend on the task, the person, and the type of noise (e.g., Baker \& Holding, 1993). Noise harms performance when certain combinations of employee, task, and type of noise co-occur, but not under some other circumstances. For certain tasks, noise may even arouse an employee enough to improve performance (e.g., Miller, 1974). Noise is a serious problem in modern open-plan offices. Employees find sound a problem both coming and going: sound entering their workspace is annoying, and when their own words escape over partitions too easily their privacy is compromised (Hedge, 1982). Office noise may even affect important interpersonal behavior, from mere impressions of others to important judgments regarding them (Sauser, Arauz, \& Chambers, 1978). Some research suggests that long-term exposure to loud sounds has serious 


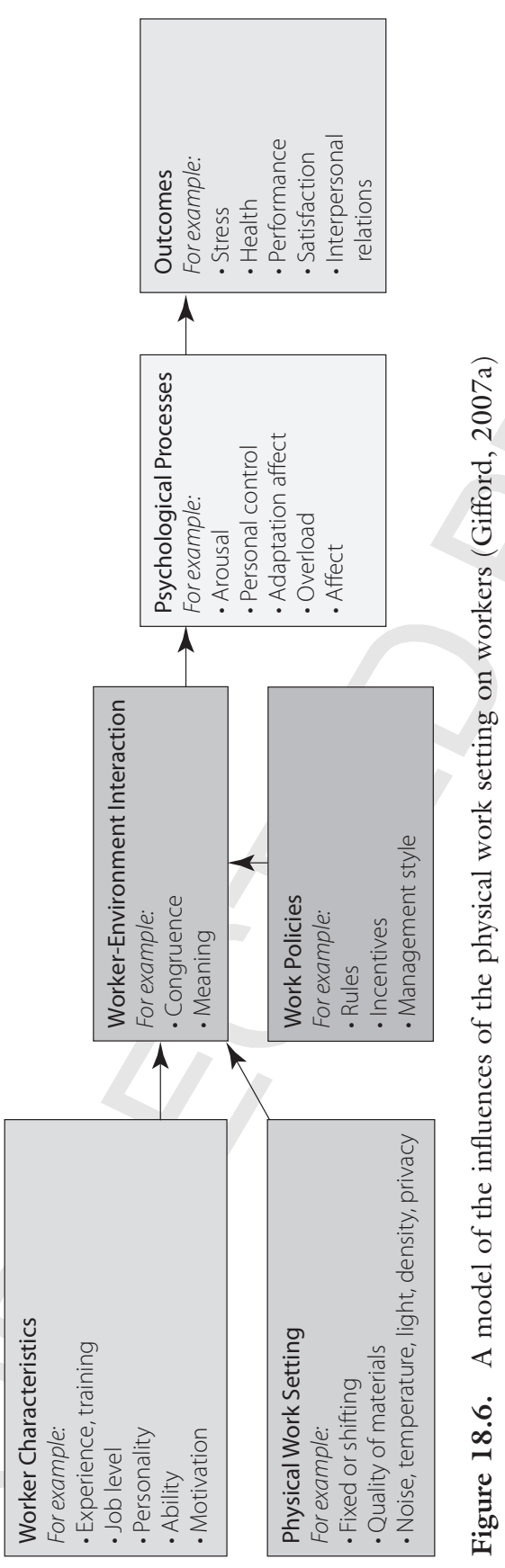

Se 
physiological effects beyond hearing loss, such as increased cardiovascular problems (Welch, 1979).

Indoor climate is measured by effective temperature, which includes humidity and air movement as well as temperature. Relatively extreme effective temperatures do not affect many work behaviors unless core body temperature is altered. The effects of temperature are also usually damped by access to heavier or lighter clothing. The amazing variety of temperature effects reported are partly the result of these measurement and clothing factors, as well as many others including degree of acclimatization, knowledge of coping strategies, motivation, and type of work (Gifford, 2007a, p. 385 ). Engineers have outlined well-described comfort envelopes, but environmental psychologists have discovered that comfort depends on perception as well as actual effective temperature and that optimal performance may be found outside the comfort envelope (Nelson, Nilsson, \& Hopkins, 1987). Temperature stress occurs when individuals are initially subjected to temperatures far outside the comfort zone, but many people can adapt to these more extreme temperatures after longer-term exposure to them.

Several components of air-including carbon monoxide, air ions, and bad odorsmay affect performance, but the effects are not striking under normal conditions (National Academy of Sciences, 1977). When it carries chemical impurities or diseasecausing organisms, it can seriously impair health. Lack of control over noticeably bad air may affect persistence at work and, in some circumstances, foster negative feelings among employees.

Light affects work behavior primarily when it is quite insufficient (leading to low productivity and accidents) or improperly placed (leading to glare and eyestrain). A meta-analysis showed that within the normal range, increased illumination improves performance (Gifford, Hine, \& Veitch, 1997). Many employees dislike fluorescent and other newer forms of lighting, some of which distort color (Megaw \& Bellamy, 1983). Carefully placed local lighting could resolve some of these problems. Access to natural light and views is psychologically important.

Naturally occurring spatial arrangements have few documented effects on performance, but employees are very sensitive to space, and unhappy with many existing arrangements (Ng \& Gifford, 1984). Many open-plan arrangements reduce desirable communication and increase undesirable communication (Zalesny \& Farace, 1987). Office arrangements lead visitors to form impressions of the office-holder's character and status (Morrow \& McElroy, 1981). Many organizations restrict the degree to which employees may arrange or personalize their offices and fail to adequately consult employees when offices are planned.

Environmental psychologists have been involved in the design of many work settings, from basic noise and light consultations to complete office designing. Better office designs are not only a basic right of employees, but they also save money for organizations. A comprehensive study found that improved layout and enclosure in offices would lead to productivity increases of $15 \%$ for managers and professional-technical employees, and $\mathbf{1 7 . 5 \%}$ for clerical workers (Brill, Margulis, \& Konar, 1984). Similar studies report 10 to $50 \%$ increases with better workplace designs (Gifford, 1992). 


\begin{abstract}
After work
The environmental psychology of travel is a new but growing area. Travelers affect destinations and are affected by them. Anticipation, travel, and recollection of travel involve environmental perception and cognition (Iso-Ahola, 1983). Recreational travel is an environmental trade-off, but as society is able to provide employees with more disposable income and time, it is a trade-off many are pursuing. Destination selection, acquisition of knowledge about destination, and behavior along the road are a few areas of developing research. Some destinations bring relief from anxiety; others throw travelers into environment shock (Pearce, 1981). Travelers ruin some physical settings and enhance almost none; romantic tourism is an undesirable luxury because it degrades natural settings (Walter, 1982). More careful planning of destination sites might spread the impact of visitors, offer more authentic experiences, and educate travelers while offering them solace from the working world.
\end{abstract}

\title{
Natural Environmental Psychology
}

The natural environment has been approached within environmental psychology in a variety of ways, with some appreciation of the fact that the natural environment was and remains the encompassing environment of which humans are an integral and adaptive part, notwithstanding some 30,000 years of extensive human alteration. The natural environment has been seen (a) as a complex stimulus environment for which we have hard-wired and functional sensitivities, preferences, and aversions (Ornstein \& Ehrlich, 2000), (b) as the source of aesthetic appreciation and creative and spiritual inspiration (Williams \& Harvey, 2001), (c) as part of fondly remembered and formative childhoods for many (Chawla, 1994; Ittelson, Proshansky, Rivlin, \& Winkel, 1974), (d) as the basis of our planet's and our species' life support systems and the critical object of conservation initiatives (Schmuck \& Schultz, 2002), (e) as a restorative and therapeutic venue and refuge from the overload and stresses of modern life (Hartig \& Staats, 2003; Kaplan, 1995), (f) as an important design and planning criterion and set of principles for creating beautiful, comfortable, and life-enhancing human structures and settings (Thompson, 2000), and (g) as moral compass and existential and aesthetic touchstone (e.g., Berleant \& Carlson, 2004).

Nature has both awesome power to disrupt lives or to act as a restorative agent. People have always believed that nature is restorative. The various ways in which it is restorative include facilitating cognitive freedom, ecosystem connectedness, escape, challenge, growth, guidance, a renewed social life, and health (Gifford, 2007a). Being in nature (e.g., Sullivan, Kuo, \& DePooter, 2004), and even merely viewing nature (e.g., Ulich, 1984), have restorative effects, although some researchers maintain that the same effects might be gained by features of nature that also may be found in civilization (Scopelliti \& Giuliani, 2004). The two main mechanisms by which nature restores us are through refreshing attentional capacity (Kaplan, 1995) and improving mood.

The natural environment continues to be a very diverse domain of applied environmental psychological work, both in the context of designing 'nature' into human 
settings (Kaplan, Kaplan \& Ryan, 1998) and in the context of designing with nature in mind (McHarg, 1991). The importance of acknowledging and incorporating the natural environment in planning and design is particularly salient in the context of health, well-being, and restoration benefit, with an extensive evidence base spanning three decades and myriad institutional and urban applications and settings (Hartig \& Staats, 2003; Maller, Townsend, Prior, Brown, \& St. Leger, 2006). These restoration benefits and indeed more fundamental psychological needs and processes have also been more widely acknowledged and embraced in clinical and counselling practice.

\section{The Social Construction of Nature, the Environment, and Environmental Problems}

"The environment," "nature," and other constructs used for referring to places, landscapes, homelands, and human settings are simultaneously constructions and idealized places as well as objective environments (e.g., Grauman \& Kruse, 1990; Macnaghten \& Urry, 1998). However, environmental psychologists have mainly focused on physical environments as the objectified research setting, with less consideration given to perceptual, cognitive, affective, social, cultural, and symbolic processes that are integrally involved in how we experience, understand, respond to, and transact with "objective" and "meaning-full" environments. Rich literatures exist on place meaning and attachment (Altman \& Low, 1992), phenomenological ecology and environmental psychology (Seamon \& Mugerauer, 1995), the conceptual and symbolic domain of place and placelessness, landscape and meaning (e.g., Berleant, 1997), and the status and implications of constructed spaces, places, and worlds (e.g., Robertson et al., 1996), but this important work is not well reflected in current urban and regional planning and environmental impact assessment, where dramatic changes to important places continue to exact appreciable human distress and costs (Van den Berg, Hartig, \& Staats, 2007). Individual and sociocultural constructions of place and environment pose multiple challenges when issues related to risk, beauty, place meaning, environmental values, concerns, and behavioural intentions are involved. This is because the way we think about environmental risks, problems, and environmental quality profoundly influences the decisions we make, the environments we design and build, the intervention strategies and solutions we initiate in the face of perceived threats, and how we experience, respond, and adapt to our objectively 'real' natural and built environments.

\section{Environmental Psychology and Architectural Design}

Some buildings are human disasters; others are merely persistent nuisances to those who use them. Social design (Sommer, 1983) is a way of creating buildings that fit occupants and users better by involving them in the planning process. Social design is a remedy for the malady in which architects see themselves primarily as artists, ignoring the basic needs and activities of occupants. This is now widely recognized, yet many buildings are still constructed without significant user involvement. 
Social design has numerous goals, problems and advantages. It aims to match settings to their occupants, to satisfy a variety of principal players' needs, to promote personal control in the building, and to encourage social support (Gifford, 2007a). Under some circumstances, other goals may be to increase productivity or to change behavior. The problems include a frequent lack of communication between those who pay for a building and those who use or occupy it, resistance to the extra effort of involving users and occupants, unrealistic expectations that socially designed buildings will directly cure various evils, conflict among principal players, and the false beliefs that some designers hold about those who will use a building (e.g., Heimsath, 1977). Social design usually means serving the needs of building occupants first, but it also offers benefits to architects and paying clients.

The design process includes programming, design, construction, use and adaptation, and postoccupancy evaluation (Zeisel, 1981). Programming consists of three phases: understanding the needs of building users, involving them in the possibilities of design, and translating their needs into design guidelines. Turning these guidelines into plans and reality is the job of architects and construction companies. The environmental psychologist returns later to conduct a postoccupancy evaluation, which examines the effectiveness of the program and design (e.g., Preiser, Vischer, \& White, 1991).

\section{Information and Communication Technologies and Environments}

Perhaps the most profound global environmental change that has taken place during the emergence and development of environmental psychology has been the revolution in information technology. These profound changes have been commented upon by many (Hassan, 2008; McLuhan, 1964), but perspectives from psychologists are particularly helpful with respect to what these changes might portend for psychology, environmental psychology and environmental sustainability (Stokols \& Montero, 2002; Subrahmanyam \& Greenfield, 2009).

These convergent technologies are most compelling because they are transforming not only our technological extensions (Hall, 1976) and information environments (Norman, 2008), but the very nature of our transactions with, and understandings of, our natural and social environments. These technologies also pose challenges to optimal human functioning, human settings, and sustainable human-natural environment transactions (Stokols, Misra, Runnerstrom, \& Hipp, 2009). Research on restoration, environmental stress, and virtual environment design suggest that this distancing of experience through mediated transactions and encounters with natural and actual environments fundamentally changes our connections with our world and how we view these connections, ourselves, and our world (Levi \& Kocher, 1999; Reser, 2009). Transactional approaches have always addressed the nature and quality of the information and feedback provided during environmental transactions (e.g., Altman, 1990; Reser, \& Scherl, 1988), but the profound information technology transformations taking place as we enter this brave new world of screen culture, cyberspace, and virtual interactive experience requires a considered and perhaps radi- 
cally different understanding of environmental transactions, and a re-examination of prevailing assumptions about direct perception and the nature of representation (e.g., Heft, 2001).

\section{Conclusion-Changing Contexts, Horizons, and Challenges}

Environmental psychology has been from its inception a moving target and enterprise, with reviews and characterizations often out of step with current involvements and applications, and ongoing changes. Of the many myriad strands to this, a number of transitions and challenges appear to be particularly noteworthy:

- Dramatically changing information technologies and information environments are fundamentally altering our transactions with the larger world-and with each other (Stokols et al., 2009; Subrahmanyam \& Greenfield, 2009).

- Ecological psychology continues to challenge environmental psychology with respect to the nature and status of direct perception and experience (Heft, 2001; Reser, 2007), particularly in a world increasingly characterized by indirect and virtual experience and mediated "realities".

- Environmental psychology's increasing interest in the challenges and paradoxes of the local and global (Gifford et al., 2009; Uzzell, 2000) finds itself in a quandary, where thinking globally, acting locally, and responding personally are prerequisite for a sustainable existence, but are compromised by a convergent set of perceptual, media coverage, and information and communication technology biases.

- Problems related to distinctions between the physical and social environment have never been adequately resolved (Heft, 1998; Kaplan \& Kaplan, 2009), but the changing nature of human settings and virtual "physical" and "social environments," and the intertwined nature of the biophysical and psychosocial underscores the fundamental importance of adequately conceptualizing "environmental" contexts to understanding human behaviour. Some believe that we need to reconsider alternative ways of understanding people-environment transactions (Reser \& Bentrupperbäumer, 2008; Stokols et al., 2009).

These challenges are necessarily changing the face of environmental psychology, but perhaps no changes are more profound and consequential than the cascading impacts of climate change. Its mitigation and adaptation present an enormously consequential relevancy test for the applicability and relevance of many areas of behavioral science, but particularly for environmental psychology (Gifford, 2008a; Reser, 2009; Swim et al., 2009; Steg \& Vlek, 2008; Uzzell \& Räthzel, 2009). These challenges include increasingly fragile life support systems, the continuous threat and stress of media representations and risk communications, mitigation measure themselves, and the global human costs of socioeconomic and socio-political instability and disruption around the world. Although considerable emphasis has been placed on targeting environmentally significant behaviors behaviours, for cogent and compelling reasons in the service of reducing greenhouse gases and climate change 
mitigation (e.g., Steg \& Vlek, 2008; Gardner \& Stern, 2002, 2008), equally persuasive and strategic arguments can be made for simultaneously focusing on other people-environment interfaces where the nature and outcomes of these transactions mediate both proenvironmental behaviors and the concurrent psychosocial impacts of perceived environmental changes. Each of these interfaces presents recurrent patterns of opportunities where targeted applied psychology interventions might make a substantive difference, ultimately in terms of environmentally significant behaviours (ESBs), but more immediately in terms of psychologically significant responses (Swim et al., 2009). Such an approach requires a rethinking of people-environment transactions, both directly in immediate 'real' environments, and indirectly with respect to virtual information environments.

Scientific psychology began in the 19th century, but not until the end of the 1950s was psychology's range extended in any serious way to the physical environment. From the vantage point of the early 21 st century, the outmoded vision of a psychology that attempted to understand persons in a virtually empty physical context seems woefully inadequate. Environmental psychology not only fills in the background, but also the foreground and the built and natural settings within which all of life operates. Thus, environmental psychology is not only essential to a complete theoretical understanding of people, but also for every application of psychology to the understanding and improvement of everyday life and the environments in which it occurs.

\section{References}

Aarts, H., Verplanken, B., \& Van Knippenberg, A. (1998). Predicting behaviour from actions in the past: Repeated decision making or a matter of habit? Journal of Applied Social Psychology, 28, 1355-1374.

Abrahamse, W., Steg, L., Vlek, C., Rothengatter, J. A. (2005). A review of intervention studies aimed at household energy conservation. Journal of Environmental Psychology, 25, 273-291.

Abrahamse, W., Steg, L., Vlek, C., \& Rothengatter, J. A. (2007). The effect of tailored information, goal setting and feedback on household energy use, energy-related behaviors and behavioral determinants. Journal of Environmental Psychology, 27, 265-276.

Ahrentzen, S. (1981). The environmental and social context of distraction in the classroom. In A. E. Osterberg, C. P. Tiernan, \& R. A. Findlay (Eds.), Design research interactions (pp. 241-250). Ames, IA: Environmental Design Research Association.

Ahrentzen, S., Jue, G. M., Skorpanich, M. A., \& Evans, G. W. (1982). School environments and stress. In G. W. Evans (Ed.), Environmental stress (pp. 224-255). New York: Cambridge University Press.

Ajzen, I. (1991). The theory of planned behavior. Organizational Behavior and Human Decision Processes, 50, 179-211.

Altman, I. (1975). The environment and social behavior: Privacy, personal space, territoriality, and crowding. Monterey, CA: Brooks/Cole.

Altman, I. (1990) Toward a transactional perspective: A personal journey. In I. Altman \& K. Christensen (Eds.), Environment and behavior studies: Emergence of intellectual traditions (pp 226-256). New York: Plenum.

Altman, I., \& Low, S. M. (Eds.). (1992). Human behavior and environment: Place attachment. New York: Plenum. 
Altman, I., \& Rogoff, B. (1987). World views in psychology and environmental psychology: Trait, interactional, organismic and transactional perspectives. In I. Altman \& D. Stokols (Eds.), Handbook of environmental psychology (pp. 245-281). New York: Wiley.

Appleyard, D. (1976). Planning a pluralist city. Cambridge, MA: MIT Press.

Bamberg, S. (2002). Effects of implementation intentions on the actual performance of new environmentally friendly behaviours - Results of two field experiments. Journal of Environmental Psychology, 22, 399-411.

Bamberg, S., \& Schmidt, S. (2003). Incentives, morality or habit? Predicting students' car use for university routes with the models of Ajzen, Schwartz and Triandis. Environment and Behavior, 35, 264-285.

Baker, M. A., \& Holding, D. H. (1993). The effects of noise and speech on cognitive task performance. Journal of General Psychology, 120, 339-355.

Barker, R. G. (1968). Ecological psychology: Concepts and methods for studying the environment of human behavior. Stanford, CA: Stanford University Press.

Barker, R. G., \& Gump, P. V. (Eds.). Big school, small school: High school size and student behavior. Stanford, CA: Stanford University Press.

Barnes, R. D. (1981). Perceived freedom and control in the built environment. In J. H. Harvey (Ed.), Cognition, social behavior, and the environment (pp. 409-422). Hillsdale, NJ: Erlbaum.

Baron, R. A., \& Ransberger, V. M. (1978). Ambient temperature and the occurrence of collective violence: The long hot summer revisited. Journal of Personality and Social Psychology, $36,351-360$.

Bechtel, R. B., \& Churchman, A. (Eds.). (2002). Handbook of environmental psychology. New York: Wiley.

Bell, P. A., Greene, T. C., Fisher, J. D. \& Baum, A. (2001) Environmental psychology. (5th ed.), New York: Harcourt College Publishers.

Berleant, A. (1997) Living in the landscape: Toward an aesthetics of environment. Lawrence, KA: University Press of Kansas.

Berleant, A., \& Carlson, A. (Eds.). (2004) The aesthetics of natural environments. Peterborough, Ontario: Broadview Press.

Berlyne, D. E. (Ed.) (1974). Studies in the new experimental aesthetics: Steps toward an objective psychology of aesthetic appreciation. New York: Halsted Press.

Biel, A., \& Garling, T. (1995). The role of uncertainty on resource dilemmas. Journal of Environmental Psychology, 15, 221-233.

Black, J. S., Stern, P. C., \& Elworth, J. T. (1985). Personal and contextual influences on household energy adaptations. Journal of Applied Psychology, 70, 3-21.

Bonnes, M., Giuliani, M. V., Amoni, F., \& Bernard, Y. (1987). Cross-cultural rules for the optimization of the living room. Environment and Behavior, 19, 204-227.

Bonsall, P., Spencer, A., \& Tang, W. (1983). Ridesharing in Great Britain: Performance and impact of the Yorkshire schemes. Transportation Research, 17, 169-181.

Brill, M., Margulis, S. T., \& Konar, E. (1984). Using office design to increase productivity. Buffalo, NY: Buffalo Organization for Social and Technological Innovation.

Brown, D., Sijpkes, P., \& MacLean, M. (1986). The community role of public indoor space. Journal of Architecture and Planning Research, 3, 161-172.

Brunswik, E. (1956). Perception and the representative design of psychological experiments. Berkeley: University of California Press.

Chawla, L. (1994). In the first country of places. New York: State University of New York Press.

Cialdini, R. B., Kallgren, C. A., \& Reno, R. R. (1991). A focus theory of normative conduct: A theoretical refinement and re-evaluation of the role of norms in human behavior. Advances in Experimental Social Psychology, 24, 201-234. 
Clayton, S., \& Brook, A. (2005). Can psychology help save the world? A model for conservation psychology. Analyses of Social Issues and Public Policy, 5, 87-102.

Cohen, S. (1978). Environmental load and the allocation of attention. In A. Baum, J. E. Singer, \& S. Valins (Eds.), Advances in environmental psychology (Vol. 1). Hillsdale, NJ: Erlbaum.

Cohen, S., \& Weinstein, N. (1982). Nonauditory effects of noise on behavior and health. In G. W. Evans (Ed.), Environmental stress. New York: Cambridge University Press.

Creekmore, W. N. (1987). Effective use of classroom walls. Academic Therapy, 22, 341-348.

Dawes, R. M., \& Messick, D. M. (2000). Social dilemmas. International Journal of Psychology, 35, 111-116.

De Groot, J. I. M., \& Steg, L. (2007). Value orientations and environmental beliefs in five countries: Validity of an instrument to measure egoistic, altruistic and biospheric value orientations. Journal of Cross-Cultural Psychology, 38, 318-332.

De Groot, J., \& Steg, L. (2008). Value orientations to explain beliefs related to environmental significant behavior: How to measure egoistic, altruistic, and biospheric value orientations. Environment and Behavior, 40(3), 330-354.

Dwyer, W. O., Leeming, F. C., Cobern, M. K., Porter, B. E., \& Jackson, J. M. (1993). Critical review of behavioral interventions to preserve the environment. Research since 1980. Environment and Behavior, 25, 275-21.

Edney, J. J. (1976). The psychological role of property rights in human behavior. Environment and Planning: $A, 8,811-822$.

Evans, G. W. (1982). (Ed.). Environmental stress. New York: Cambridge University Press.

Evans, G. W., \& Saegert S. (2000). Residential crowding in the context of inner city poverty. In S. Wapner, J. Demick, C. T. Yamamoto, \& H. Minami (Eds.), Theoretical perspectives in environment-behavior research: Underlying assumptions, research problems, and methodologies (pp. 247-267). New York: Kluwer Academic/Plenum Publishers.

Evans, G. W., \& Stecker, R. (2003). Motivational consequences of environmental stress. Journal of Environmental Psychology, 24, 143-165.

Evans, G. W., Wells, N. M., Chan, H. Y. E., \& Saltzman, H. (2000). Housing quality and mental health. Journal of Consulting and Clinical Psychology, 68, 526-530.

Freedman, J. L. (1975). Crowding and behavior. San Francisco: Freeman.

Fried, M. (1984). The structure and significance of community satisfaction. Population \& Environment: Behavioral and Social Issues, 7, 61-86.

Fujii, S., \& Gärling, T. (2003). Development of script-based travel mode choice after forced change. Transportation Research F, 6, 117-124.

Gardner, G. T., \& Stern, P. C. (2002). Environmental problems and human behavior (2nd edition). Boston, MA: Pearson Custom Publishing.

Gardner, G. T., \& Stern, P. C. (2008) The short list: The most effective actions U.S. households can take to curb climate change. Environment, 50, 12-24.

Gärling, T., Fujii, S., Gärling, A., \& Jakobsson, C. (2003). Moderating effects of social value orientation on determinants of proenvironmental intention. Journal of Environmental Psychology, 23, 1-9.

Gärling, T., \& Schuitema, G. (2007). Travel demand management targeting reduced private car use: Effectiveness, public acceptability and political feasibility. Journal of Social Issues, 63(1), 139-153.

Geller, E. S. (1987). Environmental psychology and applied behavior analysis: From strange bedfellows to a productive marriage. In D. Stokols \& I. Altman (Eds.), Handbook of environmental psychology. New York: Wiley. 
Geller, E. S. (2002). The challenge of increasing proenvironmental behavior. In R. B. Bechtel \& A. Churchman, Handbook of environmental psychology (pp. 525-540). New York: Wiley.

Gibson, J. J. (1976). The theory of affordances and the design of the environment. Paper presented at the annual meeting of the American Society for Aesthetics, Toronto.

Gifford, R. (1992). Performance and related outcomes of inadequate offices: An annotated bibliography. Report to the British Columbia Buildings Corporation.

Gifford, R. (2007a). Environmental psychology: Principles and practice (4th ed.). Colville, WA: Optimal Books.

Gifford, R. (2007b). Environmental psychology and sustainable development: Expansion, maturation, and challenges. Journal of Social Issues, 63, 199-212.

Gifford, R. (2007c). The consequences of living in high-rise buildings. Architectural Science Review, 50, 2-17.

Gifford, R. (2008a). Psychology's essential role in climate change. Canadian Psychology/ Psychologie Canadienne, 49, 273-280.

Gifford, R. (2008b). Toward a comprehensive model of social dilemmas. In A. Biel, D. Eek, T. Gärling, \& M. Gustafsson (Eds.). New issues and paradigms in research on social dilemmas. Springer.

Gifford, R., Hine, D. W., \& Veitch, J. A. (1997). Meta-analysis for environment-behavior research, illuminated with a study of lighting level effects on office task performance. In G. T. Moore \& R. W. Marans (Eds.), Advances in environment, behavior, and design (pp. 223-253). New York: Plenum.

Gifford, R., \& Lacombe, C. (2006). Housing quality and children's socioemotional health. Journal of Housing and the Built Environment, 21, 177-189.

Gifford, R., Scannell, L., Kormos, C., Smolova, L., Biel, A., Boncu, S., ... Uzzell, D. (2009). Temporal pessimism and spatial optimism in environmental assessments: An 18-nation study. Journal of Environmental Psychology, 29, 1-12.

Gifford, R., \& Steg, L. (2007). The impact of automobile traffic on quality of life. In T. Garling \& L. Steg (Eds.), Threats from car traffic to the quality of urban life: Problems, causes, and solutions (pp. 33-51). Amsterdam: Elsevier.

Gifford, R., Ward, J., \& Dahm, W. (1977). Pedestrian velocities: A multivariate study of social and environmental effects. Journal of Human Movement Studies, 3, 66-68.

Grauman, C. F., \& Kruse, L. (1990) The environment: Social construction and psychological problems. In H. T. Himmelweit (Ed.), Societal psychology (pp. 212-229). London: Sage.

Guagnano, G. A., Stern, P. C., \& Dietz, T. (1995). Influences on attitude-behavior relationships: A natural experiment with curbside recycling. Environment and Behavior, 27, 699-718.

Guest, A. M., \& Lee, B. A. (1984). How urbanites define their neighborhoods. Population o Environment: Behavioral e Social Issues, 7, 32-56.

Hall, E. T. (1966). The hidden dimension. Garden City, NY: Doubleday.

Hall, E. T. (1976) Beyond culture. Garden City, NY: Doubleday \& Company.

Hardin, G. (1968). The tragedy of the commons. Science, 162, 1234-1248.

Harland, P., \& Staats, H., \& Wilke, H. (1999). Explaining proenvironmental behavior by personal norms and the theory of planned behavior. Journal of Applied Social Psychology, 29, 2505-2528.

Hartgen, D. T. (1974). Attitudinal and situational variables influencing urban mode choice: Some empirical findings. Transportation, 3, 377-392.

Hartig, T., \& Staats, H. (Eds.). (2003). Restorative environments. Journal of Environmental Psychology, 23, 103-198. Special issue focus [Restoration]. 
Hassan, R. (2008) The information society: Cyber dreams and digital nightmares. New York: Wiley.

Hawkins, D. I., Best, R. J., \& Coney, K. A. (1983). Consumer behavior: Implications for marketing strategy. Plano, TX: Business Publications.

Hay, R. (1998). Sense of place in developmental context. Journal of Environmental Psychology, $18,5-29$.

Heath, Y., \& Gifford, R. (2002). Extending the theory of planned behaviour: Predicting the use of public transportation. Journal of Applied Social Psychology, 32, 2154-2185.

Hedge, A. (1982). The open-plan office: A systematic investigation of employee reactions to their work environment. Environment and Behavior, 14, 519-542.

Heimsath, C. (1977). Behavioral architecture: Toward an accountable design process. New York: McGraw-Hill.

Heft, H. R. (1998). Essay review: The elusive environment in environmental psychology. British Journal of Psychology, 519-523.

Heft, H. R. (2001). Ecological psychology in context: James Gibson, Roger Barker, and the legacy of William James's radical empiricism. Mahwah, N.J.: Lawrence Erlbaum.

Helson, H. (1964). Adaptation-level theory. New York: Harper and Row.

Iso-Ahola, S. E. (1983). Towards a social psychology of recreational travel. Leisure Studies, 2 , 45-56.

Ittelson, W. H. (1978). Environmental perception and urban experience. Environment and Behavior, 10, 193-213.

Ittelson, W. H., Proshansky, H. M., Rivlin, L. G., \& Winkel, G. H. (1974). An introduction to environmental psychology. New York: Holt, Rinehart, Winston.

Kantrowitz, E. J., \& Evans, G. W. (2004). The relation between the ratio of children per activity area and off-task behavior and type of play in day care centers. Environment and Behavior, 36, 541-557.

Kaplan, R., Kaplan, S. \& Ryan, R. L. (1998) With people in mind: Design and management of everyday nature. Washington, DC: Island Press.

Kaplan, S. (1995). The restorative benefits of nature: Towards an integrative framework. Journal of Environmental Psychology, 15, 169-182.

Kaplan, S., \& Kaplan, R. (2009). Creating a larger role for environmental psychology: The reasonable person model as an integrative framework. Journal of Environmental Psychology, 29(3), 387-389.

Keizer, K., Lindenberg, S., \& Steg, L. (2008). The spreading of disorder. Science, 322, 1681-1685.

Koneya, M. (1976). Location and interaction in row and column seating arrangements. Environment and Behavior, 8, 265-282.

Levi, D., \& Kocher, S. (1999) Virtual nature: The future effects of information technology on our relationship to nature. Environment and Behavior, 31, 203-226.

Levin, I., \& Louviere, J. (1981). Psychological contributions to travel demand modeling. In I. Altman, J. F. Wohlwill, \& P. B. Everett (Eds.), Transportation and behaviour (pp. 29-61). New York: Plenum.

Levine, M. (1982). You-are-here maps: Psychological considerations. Environment and Behavior, 14, 221-237.

Lindenberg, S., \& Steg, L. (2007). Normative, gain and hedonic goal-frames guiding environmental behavior. Journal of Social Issues, 63(1), 117-137.

Lofland, L. (1973). A world of strangers. New York: Basic Books.

Lynch, K. (1960). The image of the city. Cambridge, MA: MIT Press.

Lynch, K., \& Rivkin, M. (1959). A walk around the block. Landscape, 8, 24-34.

MacNaghten, P., \& Urry, J. (1998) Contested natures. London: Sage. 
Maller, C. J., Townsend, M., Prior, A., Brown, P. \& St. Leger, L. (2006) Healthy nature healthy people: "Contact with nature as an upstream promotion intervention for populations." Health Promotion International, 21, 45-54.

McHarg, I. L. (1971). Design with nature. Garden City, NY: Doubleday/Natural History Press.

McLuhan, M. (1964). Understanding media: The extensions of man. London: Routledge \& Kegan Paul.

Megaw, E. D., \& Bellamy, L. J. (1983). Illumination at work. In D. J. Oborne \& M. M. Gruneberg (Eds.), The physical environment at work. New York: Wiley.

Messick, D. M., \& Brewer, M. B. (1983). Solving social dilemmas: a review. In L. Wheeler \& O. Shaver (Eds.), Review of Personality and Social Psychology (Vol. 4, pp. 11-44). Beverly Hills, CA: Sage.

Michelson, W. (1977). Environmental choice, human behavior and residential satisfaction. New York: Oxford University Press.

Milgram, S. (1977). The individual in a social world: Essays and experiments. Reading, MA: Addison-Wesley.

Miller, J. D. (1974). Effects of noise on people. Journal of the Acoustical Society of America, $56,729-764$.

Montano, D., \& Adamopoulos, J. (1984). The perception of crowding in interpersonal situations: Affective and behavioral responses. Environment and Behavior, 16, 643-666.

Montello, D. R. (1991). Spatial orientation and the angularity of urban routes: A field study. Environment and Behavior, 23, 47-69.

Moore, G. T. (1979). Knowing about environmental knowing: The current state of theory and research on environmental cognition. Environment and Behavior, 11, 33-70.

Morrow, P. C., \& McElroy, J. C. (1981). Interior office design and visitor response: A constructive replication. Journal of Applied Psychology, 66, 646-650.

Munson, P., \& Ferguson, R. (1985). The extra-visual effects of fluorescent illumination on the behavior of school children. Unpublished manuscript, University of Victoria.

Nasar, J. L. (1989). Symbolic meanings of house styles. Environment and Behavior, 21, $235-257$.

National Academy of Sciences. (1977). Medical and biological effects of environmental pollutants. Washington, DC: National Academy of Sciences.

Nelson, T. M., Nilsson, T. H., \& Hopkins, G. W. (1987). Thermal comfort: Advantages and deviations. Ashrae Transactions, 93(1), 1039-1047.

Newman, O. (1972). Defensible space. New York: Macmillan.

$\mathrm{Ng}$, C. F. (2003). Satisfying shoppers' psychological needs: From public market to cyber-mall. Journal of Environmental Psychology, 23, 427-237.

Ng, C. F., \& Gifford, R. (1984). Speech communication in the office: The effects of background sound level and conversational privacy. Unpublished manuscript, University of Victoria.

Nickerson, R. S. (2003). Psychology and environmental change. Mahwah, NJ: Erlbaum.

Nordlund, A. M., \& Garvill, J. (2003). Effects of values, problem awareness, and personal norm on willingness to reduce personal car use. Journal of Environmental Psychology, 23, 339-347.

Norman, K. L. (2008) Cyberpsychology: An introduction to human-computer interaction. New York: Cambridge University Press.

Norris-Baker, C., \& Scheidt, R. J. (1990). Place attachment among older residents of a "ghost Town": A transactional approach. Proceedings of the 21 st annual conference of the Environmental Design Research Association, 21, 333-340.

O'Keefe, J., \& Nadel, L. (1978). The hippocampus as a cognitive map. Oxford: Clarendon Press. 
Ölander, F., \& Thøgersen, J. (1995). Understanding of consumer behaviour as a prerequisite for environmental protection. Journal of Consumer Policy, 18, 345-385.

Ornstein, R., \& Ehrlich, P. (2000). New world, new mind. Malor Books.

Passini, R., Pigot, H., Rainville, C., \& Tetreault, M. H. (2000). Wayfinding in a nursing home for advanced dementia of the Alzheimer's type. Environment and Behavior, 32, 684-710.

Patterson, M. L., \& Sechrest, L. B. (1970). Interpersonal distance and impression formation. Journal of Personality, 38, 161-166.

Pearce, P. L. (1981). Environment shock: A study of tourists' reactions to two tropical islands. Journal of Applied Social Psychology, 11, 268-280.

Poortinga, W., Steg, L., Vlek, C., \& Wiersma, G. (2003). Household preferences for energysaving measures. A conjoint analysis. Journal of Economic Psychology, 24, 49-64.

Preiser, W. F. E., Vischer, J. C., \& White, E. T. (Eds.). (1991). Design intervention: Toward a more humane architecture. New York: Van Nostrand Reinhold.

Reser, J. P. (1980). Automobile addiction: Real or imagined? Man-Environment Systems, 10, 279-287.

Reser, J. P. (2007). Ecological psychology in context: Revisiting Gibson, Barker, and James' radical empiricism - and rethinking environment and environmental experience. Journal of Environmental Psychology, 27, 1-13.

Reser, J. P. (2009). Climate change is far more than climate change: Perspectives on climate change from social and environmental psychology and social science. Journal of Environmental Psychology, under review.

Reser, J. P. \& Bentrupperbäumer, J. M. (2008). Framing and researching the impacts of visitation and use in protected areas. In N. Stork \& S. Turton (Eds.), Living in a dynamic tropical forest landscape: Lessons from Australia (pp. 420-429). Oxford: Blackwell.

Reser, J. P., \& Scherl, L. M. (1988). Clear and unambiguous feedback: A transactional and motivational analysis of environmental challenge and self encounter. Journal of Environmental Psychology, 8, 269-286.

Robertson, G., Mash, M., Tickner, L., Bird, J., Curtis, B. \& Putnam, T. (Eds.). 1996. Future Natural: Nature/science/culture. London: Routledge.

Rohe, W., \& Patterson, A. H. (1974). The effects of varied levels of resources and density on behavior in a day care center. In D. Carson (Ed.), Man-environment interactions: Evaluations and applications. Stroudsberg, PA: Dowden, Hutchinson and Ross.

Rotton, J., Frey, J., Barry, T., Milligan, M., \& Fitzpatrick, M. (1979). The air pollution experience and physical aggression. Journal of Applied Social Psychology, 9, 397-412.

Sauser, W. I., Jr., Arauz, C. G., \& Chambers, R. M. (1978). Exploring the relationship between level of office noise and salary recommendations: A preliminary research note. Journal of Management, 4, 57-63.

Schmuck, P., \& Schultz, P. W. (Eds.) (2002) Psychology of sustainable development (pp. 61-78). Boston: Kluwer.

Schultz, P. W., Nolan, J., Cialdini, R., Goldstein, N., \& Griskevicius, V. (2007). The constructive, destructive, and reconstructive power of social norms. Psychological Science, 18, $429-434$.

Schwartz, S. H. (1977). Normative influences on altruism. In L. Berkowitz (Ed.), Advances in experimental social psychology, 10 (pp. 221-279). New York: Academic Press.

Scopelliti, M., \& Giuliani, M. V. (2004). Choosing restorative environments across the lifespan: A matter of place experience. Journal of Environmental Psychology, 24, 423-437.

Seamon, D. (1982). The phenomenological contribution to environmental psychology. Journal of Environmental Psychology, 2, 119-140. 
Seamon, D., \& Mugerauer, R. (Eds.). 1995. Dwelling, place and environment: Towards a phenomenology of person and world. Dordrecht: Martinus Nijhoff Publishers.

Smith, S. M. (1979). Remembering in and out of context. Journal of Experimental Psychology, $5,460-471$.

Sommer, R. (1959). Studies in personal space. Sociometry, 22, 247-260.

Sommer, R. (1983). Social design. Englewood Cliffs, NJ: Prentice-Hall.

Stamps, A. E. (2005). Enclosure and safety in urbanscapes. Environment and Behavior, 37, $102-133$.

Steele, F. (1980). Defining and developing environmental competence. In C. P. Alderfer \& C. L. Cooper (Eds.), Advances in experiential social processes, 2, 225-244.

Steg, L., De Groot, J. I. M., Dreijerink, L., Abrahamse, W., \& Siero, F. (in press). General antecedents of personal norms, policy acceptability, and intentions: The role of values, worldviews, and environmental concern. Society and Natural Resources.

Steg, L., Dreijerink, L., \& Abrahamse, W. (2005). Factors influencing the acceptability of energy policies: testing VBN theory. Journal of Environmental Psychology, 25, $415-425$.

Steg, L., Dreijerink, L., \& Abrahamse, W. (2006). Why are energy policies acceptable and effective? Environment and Behavior, 38(1), 92-11.

Steg, L., \& Gifford, R. (2005). Sustainable transport and quality of life. Journal of Transport Geography, 13, 59-69.

Steg, L., \& Schuitema, G. (2007). Behavioural responses to transport pricing: a theoretical analysis. In T. Gärling \& L. Steg (Eds.), Threats to the quality of urban life from car traffic: problems, causes, and solutions (pp. 347-366). Amsterdam: Elsevier.

Steg, L., \& Vlek, C. (2009). Encouraging proenvironmental behaviour: An integrative review and research agenda. Journal of Environmental Psychology, 29, 309-317.

Stern, E. (1982). Bus services in rural areas. Environment and Behavior, 14, 94-112.

Stern, P. C. (2000). Toward a coherent theory of environmentally significant behavior. Journal of Social Issues, 56(3), 407-424.

Stokols, D. (1972). On the distinction between density and crowding: Some implications for further research. Psychological Review, 79, 275-278.

Stokols, D., Misra, S., Runnerstrom, M. G. \& Hipp, J. A. (2009). Psychology in an age of ecological crisis: From personal angst to collective action. American Psychologist, 64, 181-193.

Stokols, D., \& Montero, M. (2002) Toward an environmental psychology of the internet. In R. B. Bechtel \& A. Churchman (Eds.), Handbook of environmental psychology (pp. 661675). New York: Wiley.

Stokols, D., \& Shumaker, S. A. (1981). People in places: A transactional view of settings. In J. H. Harvey (Ed.), Cognition, social behavior and the environment. Hillsdale, NJ: Erlbaum.

Stokols, D., \& Shumaker, S. A. (1982). The psychological context of residential mobility and well-being. Journal of Social Issues, 38(3), 149-171.

Strang, H. R., \& George, J. R. (1975). Clowning around to stop clowning around: A brief report on an automated approach to monitor, record, and control classroom noise. Journal of Applied Behavior Analysis, 8, 471-474.

Studenmund, A. H., \& Connor, D. (1982). The free-fare transit experiments. Transportation Research, 16, 261-269.

Subrahmanyam, K., \& Greenfield, P. M. (Eds.). (2009). Social networking on the internetDevelopmental implications. Journal of Applied Developmental Psychology, 29, whole issue, 415-471.

Suedfeld, P. (1980). Restricted environmental stimulation: Research and clinical applications. New York: Wiley. 
Sullivan, W. C., Kuo, F. E., \& DePooter, S. F. (2004). The fruit of urban nature: Vital neighborhood spaces. Environment and Behavior, 36, 678-700.

Swim, J., Clayton, S., Doherty, T., Gifford, R., Howard, G., Reser, J.P., Stern, P. \& Weber, E. (2009). Psychology and global climate change: Addressing a multi-faceted phenomenon and set of challenges. Washington, DC: American Psychological Association.

Thompson, I. H. (2000). Ecology, community, and delight: Sources of values in landscape architecture. London: E. \& F. N. Spon.

Ulrich, R. S. (1984). View through a window may influence recovery from surgery. Science, $224,420-421$.

Uzzell, D. (2000) The psycho-spatial dimension to global environmental problems. Journal of Environmental Psychology, 20(4) 307-318.

Uzzell, D., \& Räthzel, N. (2009) Transforming environmental psychology. Journal of Environmental Psychology, 29(3), 340-350.

Van den Berg, A. E., Hartig, T., \& Staats, H. (2007). Preference for nature in urbanized societies: Stress, restoration, and the pursuit of sustainability. Journal of Social Issues, 63, 79-96.

Walter, J. A. (1982). Social limits to tourism. Leisure Studies, 1, 295-304.

Weinstein, C. S. (1977). Modifying student behavior in an open classroom through changes in the physical design. American Education Research Journal, 14, 249-262.

Weinstein, C. S. (1979). The physical environment of the school: A review of the research. Review of Educational Research, 49, 577-610.

Welch, B. L. (1979). Extra-auditory health effects of industrial noise: Survey of foreign literature. Aerospace Medical Research Laboratory, Aerospace Medical Division, Air Force Systems Command, Wright-Patterson AFB, June 1979.

Williams, K., \& Harvey, D. (2001). Transcendent experience in forest environments. Journal of Environmental Psychology, 21(3) 249-260.

Wohlwill, J. F. (1966). The physical environment: A problem for a psychology of stimulation. Journal of Social Issues, 22(4), 29-38.

Wollin, D. D., \& Montagne, M. (1981). College classroom environment: Effects of sterility versus amiability on student and teacher performance. Environment and Behavior, 13, $707-716$.

Zalesny, M. D., \& Farace, R. V. (1987). Traditional versus open offices: A comparison of sociotechnical, social relations, and symbolic meaning perspectives. Academy of Management Journal, 30, 240-259.

Zeisel, J. (1981). Inquiry by design: Tools for environment-behavior research. Monterey, CA: Brooks/Cole. 